\title{
Influence of depth of sowing, herbicide incor- poration and temperature on metolachlor and EPTC toxicity to corn (Zea mays L.)
}

\author{
Paul GAILLARDON, Serge SIMON \& René SCALLA \\ I.N.R.A., Laboratoire des herbicides, BV 1540, F 21034 Dijon Cedex
}

\begin{abstract}
Biological tests, done in a clay loam soil with a charcoal barrier technique, were used to determine the influence of depth of sowing, herbicide incorporation, and temperature on metolachlor and EPTC toxicity to young corn (Zea mays L.) seedlings. Metolachlor induced growth inhibition when depth of sowing was decreased from 55 to $22 \mathrm{~mm}$, herbicide incorporation increased from 4 to $16 \mathrm{~mm}$, and temperature raised from 17 to $24{ }^{\circ} \mathrm{C}$ Phytotoxicity was closely related to the presence of the coleoptile node in the treated layer. Deep sowing and low temperature favoured a deeper position of the coleoptile node in soil, and therefore decreased corn susceptibility to metolachlor. Inhibition of mesocotyl growth by coleoptile-transmitted light is likely to explain the effect of these factors. In presence of an antidote (dichlormid), high doses of EPTC could reduce mesocotyl growth but did not severely injure corn seedlings.
\end{abstract}

Additional key words: Mesocotyl growth, coleoptile node position, light effect.

Influence de la profondeur de semis, de l'incorporation de l'herbicide et de la température sur la toxicité du métolachlore et de l'EPTC pour le maïs (Zea mays).

Des tests biologiques, réalisés avec un sol argilo-limoneux et utilisant une barrière de charbon actif pour confiner l'herbicide, ont permis d'étudier l'influence de la profondeur du semis, de l'incorporation de l'herbicide et de la température sur la phytotoxicité du métolachlore et de l'EPTC pour de jeunes plantules de maïs (Zea mays $\mathrm{L}$.). Les résultats montrent que le métolachlore peut réduire la croissance des plantes quand la profondeur du semis diminue de 55 à $22 \mathrm{~mm}$, l'incorporation de l'herbicide augmente de 4 à $16 \mathrm{~mm}$ et la température s'élève de 17 à $24^{\circ} \mathrm{C}$. La phytotoxicité est étroitement liée à la présence du næud de coléoptile dans la couche traitée. Un semis profond et une température basse favorisent l'établissement du nœud de coléoptile en profondeur et diminuent la sensibilité du maïs au métolachlore. L'inhibition de la croissance du mésocotylc par la lumière transmise par le coléoptile est susceptible d'expliquer cet effet. En présence d'un antidote (dichlormide), de fortes doses d'EPTC peuvent réduire la croissance du mésocotyle, mais n'affectent pas gravement la croissance des plantules de maïs.

Mots clés additionnels : Croissance du mésocotyle, position du noud de coléoptile, effet de la lumière.

\section{INTRODUCTION}

Chloroacetanilide and thiocarbamate herbicides are commonly used for selective weed control in corn. However, metolachlor (2-chloro-N-(2-ethyl-6-methylphenyl)-N-(2-methoxy-1-methylethyl)-acetamide) and EPTC (S-ethyl dipropylthiocarbamate) have been reported to occasionally induce some injury to this crop when the weather is warm or cold, respectively, during germination (MORIN et al., 1986).
The causes of these toxicities are not clearly understood. It has been demonstrated that shoot uptake is of particular importance for the activity of metolachlor (DiXoN \& STOLleR, 1982) and EPTC (APPLEBY et al., 1965 ; Parker, 1966 ; Prendeville et al., 1967). In a comprehensive study, PARKER (1963) has shown that the phytotoxicity of diallate, a thiocarbamate herbicide, depends on depth of sowing and herbicide incorporation in soil. Damage to wheat and barley is lowered by deeper sowing, while toxicity to oat and wild oat remains unchanged. Parker has established that diallate 
is highly toxic to oat when applied to the coleoptile node area. The specific elongation of mesocotyl is responsible for the susceptibility of this species because it brings the highly sensitive part of the plant into the superficial soil layer which contains the herbicide. In the same way, corn germination is followed by a phase of mesocotyl elongation but a decrease in alachlor toxicity with deeper sowing has been reported without any explanation having been proposed (NARSAIAH \& HARVEY, 1977).

The aim of this study was thus to analyze the role of depth of sowing, herbicide incorporation, and temperature for metolachlor and EPTC toxicity to corn, with special attention being given to the position of the coleoptile node. Moreover, the effect of light was also examined since that factor controls early development of grass seedlings through inhibition of mesocotyl and stimulation of coleoptile growth (MANDOLI \& BRIGGS, 1981 ; SCHAFER et al., 1982).

\section{MATERIALS AND METHODS}

\section{A. Effects of depth of sowing and herbicide incorporation}

Corn (var. Dea) was cultivated in plastic pots $(8 \mathrm{~cm}$ diameter and $8 \mathrm{~cm}$ high) filled with a sieved $(0.5$ to $2 \mathrm{~mm}$ ), air-dried clay loam soil (33\% clay, $2.3 \%$ organic matter, $\mathrm{pH}=7.5)$. Proportionality between height and weight of soil in the pots allowed ready formation of layers with precise thicknesses. Thus combinations of various depths of sowing and herbicide incorporation in the superficial soil layer could be carried out in pots. A $6 \mathrm{~mm}$ layer of soil with $1 \%$ charcoal was set below the treated layer as a barrier to herbicide movement.

Treated soil for the superficial layer was prepared separately by spreading an aqueous solution of formulated herbicide on a $1 \mathrm{~cm}$ soil bed $(4 \mathrm{ml} / 100 \mathrm{~g})$. The soil was allowed to dry, except for EPTC treatments, then thoroughly mixed. Herbicide rates were calculated by taking into account the area and weights of the treated layers in pots, and expressed as g a.i. ha'.

For experiments with metolachlor, four pregerminated corn seeds $\left(28 \mathrm{~h}\right.$ at $\left.25^{\circ} \mathrm{C}\right)$ were sown in each pot at 22,38 , or $55 \mathrm{~mm}$ depth. Formulated herbicide (Duclor, $960 \mathrm{~g}$ a.i. $1^{\mathrm{l}}$ ) was applied at $0,3750,7500$, or $11250 \mathrm{~g}$ a.i. ha $\mathrm{a}^{-1}$ and incorporated in a $4 \mathrm{~mm}$ thick soil layer, or at $0,1500,2250,3000$, or $3750 \mathrm{~g}$ a.i. ha ${ }^{1}$ and incorporated in a 8 or $16 \mathrm{~mm}$ layer.

For EPTC studies, corn was sown at 22 or $55 \mathrm{~mm}$. Formulated herbicide (Capsolane, containing $360 \mathrm{~g}$ a.i. $1^{1}$ and $30 \mathrm{~g}$ a.i. $1^{-1}$ dichlormid phytoprotectant) was applied at 0, 60000, or $75000 \mathrm{~g}$ a.i. ha ' and incorporated in a 8 or $16 \mathrm{~mm}$ thick layer, or at $0,11050,22100$, or $44200 \mathrm{~g}$ a.i. ha ${ }^{\prime}$ and incorporated in a $50 \mathrm{~mm}$ layer.

Soil moisture content was set to $20 \%(\mathrm{w} / \mathrm{w})$ with Hewitt nutrient solution spread on each soil layer successively added in a pot. Pots were placed in a growth chamber at $24{ }^{\circ} \mathrm{C}$ and $16 \mathrm{~h}$ light ( 15000 lux), approximately $1 \mathrm{~h}$ before the outset of light period. They were covered with a transparent plastic sheet which limited water evaporation and therefore water movement in soil. That sheet was removed at coleoptile emergence, which occurred about 40 and $55 \mathrm{~h}$ after superficial and deep sowing, respectively. Pots were then watered twice a day to a constant weight, in order to keep soil moisture as constant as possible.

Growth measurements were carried out nine days after sowing, when plants had three leaves. Distance $\left(\mathrm{H}_{1}\right)$ from the second leaf tip of each plant to the soil surface was first determined. Plants were then harvested and distance $\left(\mathrm{H}_{2}\right)$ from the second leaf tip to the coleoptile node was measured, as well as mesocotyl length. Difference between $\mathrm{H}_{2}$ and $\mathrm{H}_{1}$ provided an estimation of coleoptile node depth in soil. Measurements were averaged on the four plants of each pot and experiments were conducted with four replicates.

\section{B. Effect of temperature}

In order to evaluate the effect of temperature on herbicide phytotoxicity, the above experiments were repeated at lower temperature. Pots were placed at $17^{\circ} \mathrm{C}$ for one week until first leaf unrolling. They were then moved to a chamber at $24^{\circ} \mathrm{C}$, which allowed better plant growth. Measurements were done as previously, one week later. In these experiments, metolachlor was only incorporated down to 8 or $16 \mathrm{~mm}$.

\section{Effect of light}

In this experiment metolachlor was applied at $3700 \mathrm{~g}$ a.i. ha ${ }^{1}$ and incorporated in a $8 \mathrm{~mm}$ soil layer. Pregerminated corn seeds were sown at $55 \mathrm{~mm}$ depth. Plants were grown at $24^{\circ} \mathrm{C}$ and kept in dark for increasing periods $(55,59,63$, and $67 \mathrm{~h}$ after sowing) before light exposure. Nine-day-old plants were measured as previously. Experiment was conducted with four replicates.

\section{Statistics}

Data from each experiment was submitted to analysis of variance (SNEDECOR \& COCHRAN, 1967) and means were compared using Newman and Keuls test at $P=0.05$ (DAgnelie, 1970).

\section{RESULTS}

Metolachlor phytotoxicity to corn seedlings was evaluated by measurements of shoot lengths (distance from second leaf tip to coleoptile node: $\mathrm{H}_{2}$ ), coleoptile node depths, and mesocotyl lengths (fig. 1). Shoot growth of untreated plants did not change with depth of sowing. Shallow incorporation $(4 \mathrm{~mm})$ of herbicide only reduced shoot growth of superficially sown plants treated with high doses. Middle incorporation $(8 \mathrm{~mm})$ did not influence shoot growth of deeply sown plants but clearly injured plants sown more superficially at herbicide doses close to those used in field conditions (2- 


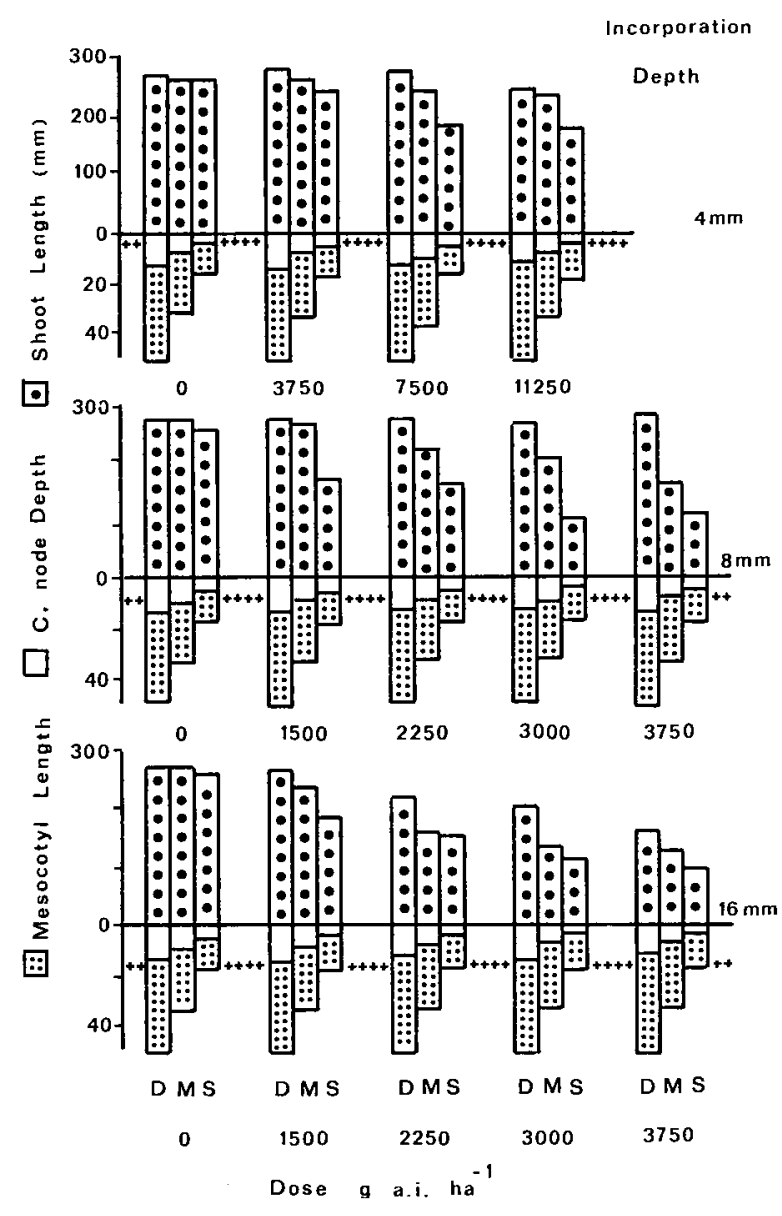

Figure 1

Effects of depth of sowing and herbicide incorporation on shoot length (distance from the second leaf tip to the colcoptile node), coleoptile node depth, and mesocotyl length of corn se'edlings treated with metolathlor. $D, M, S$ : deep ( $55 \mathrm{~mm})$, middle $(38 \mathrm{~mm})$, superficial $(22 \mathrm{~mm})$ sowing. Standard error was respectively 13.2,0.9 and $0.6 \mathrm{~mm}$ for each set of measurements.

Effets de la profondeur du semis et de l'incorporation de l'herhicide' sur la taille (de l'extrémité de la deuxième féuille au noud de coléoptile), la profondeur du nexud de coléoptile el la longueur du mésocotyle des plantules de maïs traitées au métolachlore. D. M, S : semis profond $(55 \mathrm{~mm})$, intermédiaire $(38 \mathrm{~mm})$, superficicl $(22 \mathrm{~mm})$. Pour chaque série de mesures, l'erreur standard raut respectivement 13,2, 0.9 at $0.6 \mathrm{~mm}$.

$3000 \mathrm{~g}$ a.i. ha '). This effect increased with higher doses and more superficial sowings. Deep incorporation $(16 \mathrm{~mm})$ was phytotoxic to corn for all depths of sowing and this effect increased with herbicide dose, especially for deeply sown plants.

Metolachlor had no effect on mesocotyl length and coleoptile node depth of corn seedlings, which both increased with depth of sowing. Coleoptile nodes of superficially sown plants were located at a depth of $4.5 \mathrm{~mm}$, on average. They were just below the thinnest treated soil layer but inside the treated layer when herbicide was incorporated more deeply. Coleoptile nodes of plants sown at middle depth were located $8.4 \mathrm{~mm}$ under the soil surface. They were respectively below, just below and inside the treated layer when metolachlor incorporation depth was increased. Coleoptile nodes of deeply sown plants were located at a depth of $13.4 \mathrm{~mm}$. They were below the two most superficial treated layers, but inside the deepest one.

Measurements of plants treated with EPTC are shown in figure 2. In order to obtain responses, very high herbicide doses were included in the experiment. However, EPTC never induced severe plant injuries. Only the highest doses of deeply incorporated herbicide significantly reduced shoot growth. As previously, mesocotyl length and coleoptile node depth increased with depth of sowing. EPTC could reduce mesocotyl length and conversely increase coleoptile node depth. This effect clearly increased with herbicide incorporation and dose.

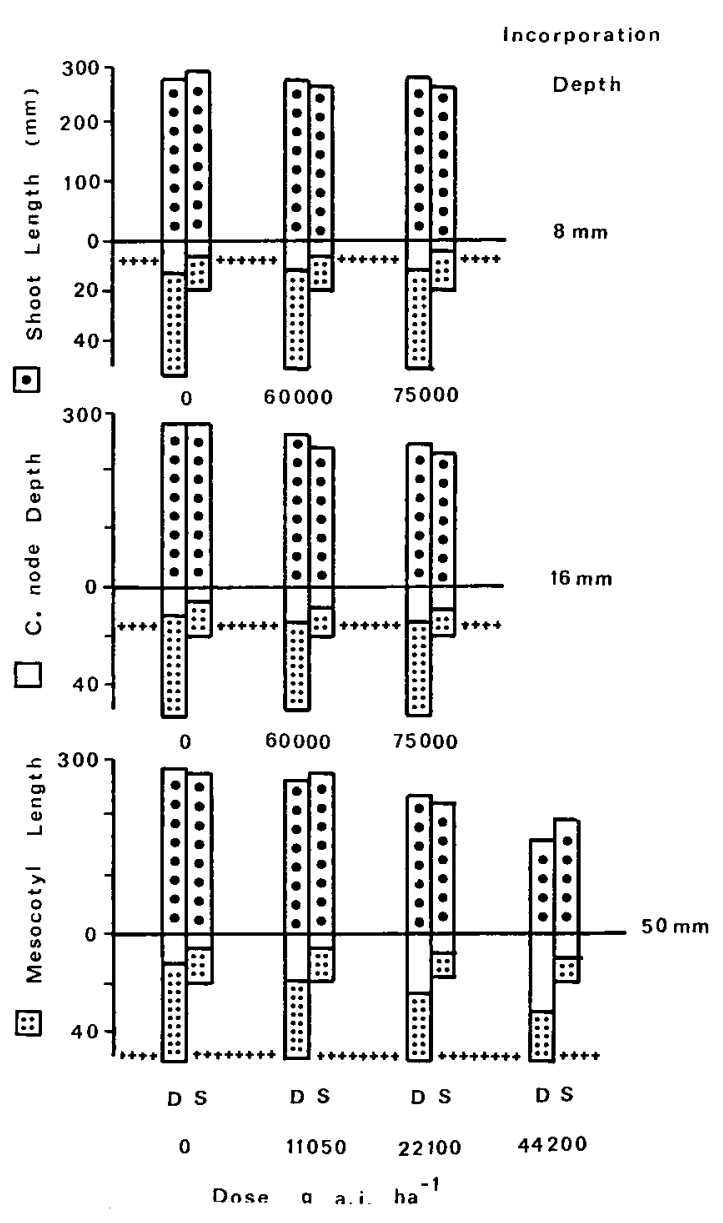

Figure 2

Effects of depth of sowing and herbicide incorporation on shoot length (distance from the second leaf tip to the coleoptile node), coleoptile node depth, and mesocotyl length of corn seedlings treated with EPTC. D, S: deep (5. mm), superficial $(22 \mathrm{~mm})$ sowing. Standard error was respecively 7.5, 0.6 and $0.5 \mathrm{~mm}$ for each set of measurements.

Effets de la profondeur du semis et de l'incorporation de l'herhicide sur la taille (de l'extrémité de la deuxième feuille au noud de col'optile) , la profondeur du norud de coléoptile et la longueur du mésocotyle des plantules de mä̈s traitées à l'EPTC. $D, S$ : semis profond $(55 \mathrm{~mm})$, superficiel (22 mm). Pour chaque série de mesures, lerreur standard vaut respectivement 7,5, 0,6 et $0,5 \mathrm{~mm}$.

The effect of temperature on metolachlor phytotoxicity, coleoptile node depth, and mesocotyl length is shown in figure 3 for controls and two herbicide doses. It appears that lower temperature could reduce metolachlor toxicity estimated from shoot lengths $\left(\mathrm{H}_{2}\right)$ and expressed as percent of controls. This effect most clearly appeared for $8 \mathrm{~mm}$ herbicide incorporation combined with middle or superficial sowing, as well as for $16 \mathrm{~mm}$ incorporation when corn was sown deeply. Low temperature decreased mesocotyl length and conversely increased coleoptile node depth. Clear differences were 


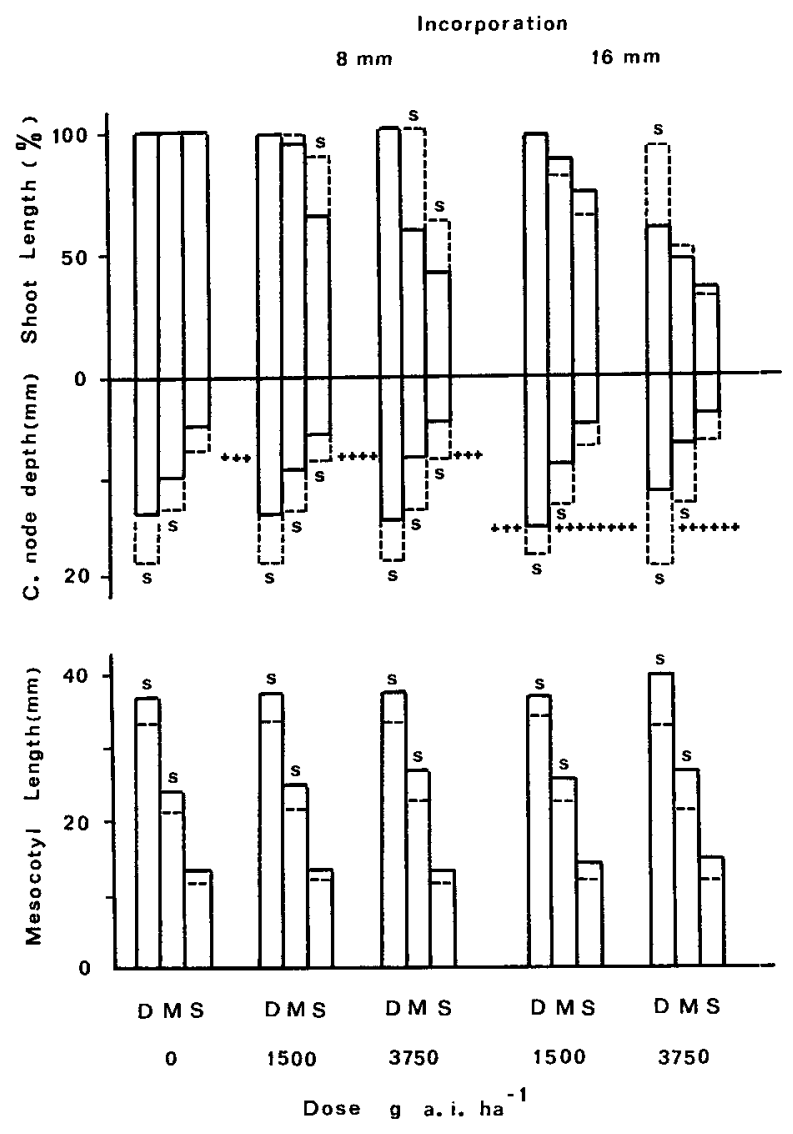

Figure 3

Effects of temperature on metolachlor toxicity to corn (shoot length as $\%$ of controls), coleoptile node depth, and mesocotyl length of corn seedlings. $D, M, S:$ deep $(55 \mathrm{~mm})$, middle $(38 \mathrm{~mm})$, superjicial $(22 \mathrm{~mm})$ sowing. Full lines correspond to $24^{\circ} \mathrm{C}$ and broken lines to $17^{\circ} \mathrm{C}$ treatments. Standard error was respectively $4.7 \%, 0.8$ and $0.6 \mathrm{~mm}$ for each set of measurements. $s$ indicates that means differ significantly.

Effets de la température sur la toxicité du métolachlore pour le maïs (taille des plantes en $\%$ des témoins), la profondeur du naud de coléoptile et la longueur du mésocotyle des plantes. $D, M, S$ : semis profond $(55 \mathrm{~mm})$, intermédiaire $(38 \mathrm{~mm})$, superficiel $(22 \mathrm{~mm})$. Les traits pleins correspondent à $24^{\circ} \mathrm{C}$ et les pointillés à $17^{\circ} \mathrm{C}$. Pour chaque série de mesures, l'erreur standard vaut respectivement $4,7 \%, 0.8$ et $0,6 \mathrm{~mm} . \mathrm{s}$ indique que les moyennes different significativement.

observed for middle and deep sowings but they were seldom significant for superficial sowing. It was noteworthy that low temperature brought the coleoptile node of plants sown at 22 and $38 \mathrm{~mm}$, respectively at the bottom and out of the $8 \mathrm{~mm}$ treated layer, while that of plants sown deeply was brought out of the $16 \mathrm{~mm}$ treated layer.

Temperature similarly influenced mesocotyl length and coleoptile node position of plants treated with EPTC, but it did not significantly change the effects of this herbicide (data not shown).

When seedlings were kept in dark for increasing periods during emergence, mesocotyl length increased and coleoptile node was brought near the soil surface (fig. 4). It was noticeable that as long as the coleoptile node was below the treated layer, plants were not injured. Its presence in the treated layer resulted in growth inhibition and this effect decreased when coleoptile node reached the soil surface.

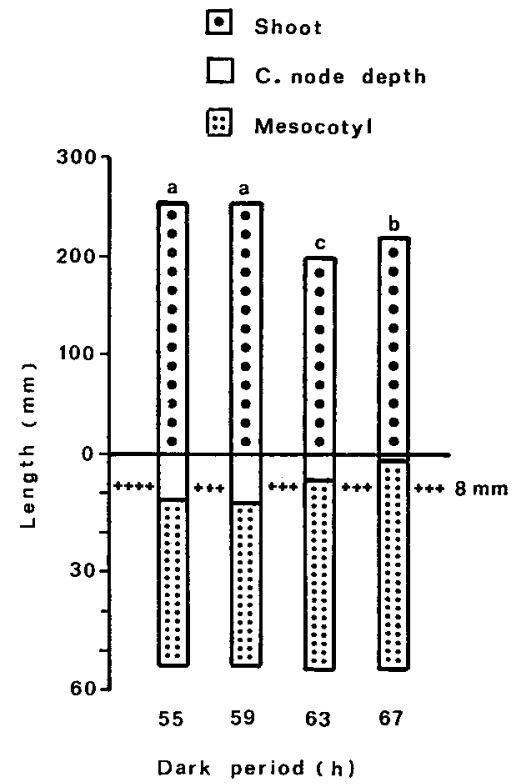

Figure 4

Effects of the duration of the dark period during emergence, on shoot length (distance from the second leaf tip to the coleoptile node), coleoptile node depth, and mesocotyl length of corn seedlings sown at $55 \mathrm{~mm}$ depth and treated with $3700 \mathrm{~g}$ a.i. ha $\mathrm{h}^{-}$of metolachlor incorporated in a $8 \mathrm{~mm}$ soil layer. Standard error was respectively 6,1 and $0.6 \mathrm{~mm}$ for each set of measurements

Effets de la durée de la période obscure, pendant la levée, sur la taille (de l'extrémité de la deuxième feuille au noud de coléoptile), la profondeur du noud de coléoptile et la longueur du mésocotyle des plantules de maïs semées à $55 \mathrm{~mm}$ de profondeur et traitées à $3700 \mathrm{~g} \mathrm{~m} . \mathrm{a} . \mathrm{ha}^{-1}$ de métolachlore incorporé dans une couche de sol de $8 \mathrm{~mm}$. Pour chaque série de mesure, l'erreur standard vaut respectivement 6,1 et $0,6 \mathrm{~mm}$.

\section{DISCUSSION}

Despite the possibility that the charcoal barrier might adsorb a higher proportion of the herbicide from the thinnest treated soil layer, it remains that metolachlor toxicity to corn increases with the depth of herbicide incorporation. As previously observed with alachlor (NARSAIAH \& HARVEY, 1977), metolachlor phytotoxicity can decrease when depth of sowing is increased, but that effect also depends on herbicide incorporation and it tends to disappear with deeper incorporation. In controlled conditions, lower temperature also reduces metolachlor toxicity, in agreement with field observations (MORIN et al., 1986).

In all experiments with metolachlor, it appears that phytotoxicity is closely related to the presence of coleoptile node in the treated soil layer. As for oats treated with diallate (PARKER, 1963), it is likely that the coleoptile node of corn seedlings constitutes a zone highly susceptible to metolachlor or, more precisely, a site of uptake close to the site(s) of action of the herbicide, which is supposed to act primarily on growing tips (ASHTON \& CRAFT, 1981; WILKINSON, 1981). On that basis, it is clear that herbicide incorporation can enhance phytotoxicity because it brings herbicide into contact with the coleoptile node. On the contrary, deep sowing and low temperature can decrease herbicide toxicity because they move the coleoptile node away from the superficial soil layer where herbicide is located. 
Effects of depth of sowing on mesocotyl elongation and coleoptile node position in soil have been described in previous studies (BLACKLOW, 1972). It has been shown that light induces growth inhibition of oat mesocotyl (MANDOLI \& BRIGGS, 1981 ; SCHAFER et al., 1982). Even if highly sensitive phytochrome located near the coleoptile node seems mainly involved, MANDOLI \& BRIGGS (1983) have emphasized the role of coleoptile acting as a fiber optic which might conduct light from the coleoptile tip to receptors near the coleoptile node. Thus, mesocotyl growth might be stopped by light at coleoptile emergence, and coleoptile node position would be mainly determined by coleoptile size. In our experiments, coleoptile emergence needs much longer time when plants are sown deeply. In these conditions, coleoptile might be taller, and thus coleoptile node stopped deeper in soil.

The action of temperature on coleoptile node position might involve the same processes, and two mechanisms may be proposed. Firstly, the growth of coleoptile might be less sensitive to temperature than that of mesocotyl, and thus coleoptile size would be taller at lower temperature. Secondly, a lag phase could take place between light exposure of coleoptile tip and stop of mesocotyl growth. Therefore mesocotyl elongation during lag phase could be less important at low temperature, and that could result in deeper coleoptile node position.

However it may be, results from study of light action on metolachlor phytotoxicity agree with the effect of light on coleoptile node position, since coleoptile node depth decreases when coleoptiles are kept in dark at emergence. These results also confirm the need for coleoptile node exposure to herbicide for phytotoxicity to occur.

Our results support the conclusion that herbicide incorporation and superficial sowing should be avoided for safe use of metolachlor in corn, especially when temperature favors rapid emergence of the crop.

In our experiments, EPTC has shown little phytotoxicity. This is probably due to the presence of the antidote (dichlormid) in the herbicide formulation. However, mesocotyl growth appears susceptible to EPTC, especially when herbicide incorporation leads to mesocotyl exposure.

Reçu le 11 avril 1988 Accepté le 11 mai 1988.

\section{REFERENCES}

Appleby A. P., Furtick W. R., Fang S. C., 1965. Soil placement studies with EPTC and other carbamate herbicides on Avena sativa. Weed Res., 5, 115-122.

Ashton F. M., Craft A. S., 1981. Mode of action of herbicides. Second Edition. Wiley Interscience Publication. John Wiley \& Son. 91-117.

Blacklow W. M., 1972. Influence of temperature on germination and elongation of the radicule and shoot of corn (Zea mays L.). Crop Science, 12, 647-650.

Dagnelie P., 1970. Théorie et méthodes statistiques. Vol. 2. Les Presses Agronomiques de Gembloux ASBL. Ed. J. Duculot S.A. Gembloux. 241-261.

Dixon G. A., Stoller E. W., 1982. Differential toxicity, absorption, translocation and metabolism of metolachlor in corn (Zea mays) and yellow nutsedge (Cyperus esculentus). Weed Sci., 30, 225-230.

Mandoli Dina F., Briggs W. R., 1981. Phytochrome control of two low-irradiance responses in etiolated oat seedlings. Plant Physiol., 67, 733-739.

Mandoli Dina F., Briggs W. R., 1983. Physiology and optics of plant tissues. What's New in Plant Physiology, 14, 4, 13-16.
Morin C., Porte-Laborde A., Naibo B., 1986. Phytotoxicités sur jeunes maïs. Agromaïs, février, 38.

Narsaiah D. B., Harvey R. G., 1977. Alachlor placement in soil as related to phytotoxicity to maize seedlings. Weed Res., 17, 163-168.

Parker C., 1963. Factors affecting the selectivity of 2,3dichloroallyldiisopropylthiolcarbamate (diallate) against Avena spp. in wheat and barley. Weed Res., 3, 259-276.

Parker C., 1966. The importance of shoot entry in the action of herbicides applied to the soil. Weed Sci., 14, 117-121.

Prendeville G. N., Eshel Y., Schreiber M., 1967. Site of uptake of soil-applied herbicides. Weed Res., 7, 316-322

Schafer E., Lassig T. U., Schopfer P., 1982. Phytochrome controlled extension growth of Avena sativa L. seedlings. II. Fluence rate response relationships and action spectra of mesocotyl and coleoptile responses. Planta, 154, 231-240.

Snedecor G. W., Cochran W. G., 1967. Statistical methods. Sixth Edition. The Iowa State University Press, Ames, Iowa, USA. 259-380 Wilkinson R. E., 1981. Metolachlor inhibition of gibberellin precursor biosynthesis. Pestic. Biochem. Physiol., 16, 199-205. 